\title{
IAMJ
}

INTERNATIONAL

AYURVEDIC

MEDICAL JOURNAL

Review Article

ISSN: 2320-5091

Impact Factor: 6.719

\section{ARTICLE ON ADOLESCENT NUTRITIONAL ANEMIA WITH SPECIAL REFERENCE TO GIRLS}

\author{
Verma Annu ${ }^{1}$, VermaKeerti ${ }^{2}$, Pandey Reena ${ }^{3}$ \\ ${ }^{1} \mathrm{MD}$ Scholar $\left(2^{\text {nd }}\right.$ Year) in Department of Kaumarbhritya at Rishikul Campus, UAU, Haridwar, Uttarakhand, India \\ ${ }^{2}$ HOD in Department of Kaumarbhritya at Rishikul Campus, UAU, Haridwar, Uttarakhand, India \\ ${ }^{3}$ Prof. in Department of Kaumarbhritya at Rishikul Campus, UAU, Haridwar, Uttarakhand, India
}

Corresponding Author: vermaanu3012@gmail.com

https://doi.org/10.46607/iamj2709092021

(Published Online: September 2021)

Open Access

(C) International Ayurvedic Medical Journal, India 2021

Article Received: 11/08//2021 - Peer Reviewed: 30/08/2021 - Accepted for Publication: 31/08/2021

Check for updates

\begin{abstract}
Nutritional anaemia is a major health problem worldwide. Adolescent girls are the most vulnerable group of the population due to different reasons. Adolescence is a stage of transition from childhood to adulthood. Adolescence is a physiological \& social process through which a child matures into an adult adolescent, comprised of 10-19 years old, from the largest generation of young people in our history.

Nutritional anaemia is a serious health problem in Indian school children. A high prevalence of anaemia has been reported in non-pregnant adolescent girls. Adolescent girls are most vulnerable to the influences of cultural \& gender norms, which often discriminate against them. Dietary patterns and physical activity in addition to schooling $\&$ countervailing social norms for early marriage influence the health and nutritional well-being of adolescents. At this age girls having menses and menarche age (10-13 years). In this age nutrients, requirements of iron further increase. This review article purposes the effect of various ayurvedic drugs on anaemia from the existing literature.
\end{abstract}

Keywords: Ayurveda, nutritional anaemia, Pandu Roga, Adolescent girls.

\section{INTRODUCTION}

Adolescence is a unique period of nutritional vulneranormal puberty development, linear growth \& neurobility. The complex hormonal interplay necessary for development change cannot occur without adequate 
nutritional fuel. ${ }^{(1)}$ Adolescent specific recommendations for nutritional intake differ significantly from adult or child recommendations. ${ }^{(2)}$ Nutritional requirements about body size are more during adolescence. ${ }^{(3)}$ In India with varying social customs \& common beliefs against females there is a high prevalence of malnutrition amongst girls. ${ }^{(4)}$ Nutritional anaemia, according to the WHO, is a state in which the haemoglobin concentration in the blood is lower for age, gender, physiologic state $\&$ altitude. As a consequence of shortage of essential nutrients, independent of the cause of this deficiency. ${ }^{(5-6)}$ Nutritional anaemia include a lack of nutrients such as iron, folic acid, Vit B12, copper and vitamins C, E \& A. Iron deficiency anaemia is the most prevalent form of nutritional disorder in infancy. It also affects communities not only in developing nations but also in highly industrialized countries. ${ }^{(7)}$ In Ayurveda the disease Pandu roga can be compared with that of anaemia, especially owing to the clinical manifestation of panduta or pallor in the whole body. Pandu roga is pitta pradhana tridoshja vyadhi. The decreased level of Rasa and Rakta which have the major functions of nourishment and providing support to the vital function gives rise to the symptoms. ${ }^{(8)}$ In rural areas/ low socioeconomic areas girls are getting married at an early age. Adolescent mothers belonging to poor socioeconomic strata suffer more because chronic undernutrition retards skeleton growth \& maturation. Adolescent girls with height $<145 \mathrm{~cm} \&$ weight $<38 \mathrm{~kg}$ is at risk for delivering low birth weight babies. ${ }^{(9)}$ According to the national nutrition monitoring bureau of India, $75 \%$ of adolescents girls are anaemic with a high incidence of deficiency of iron, folic acid \& micronutrients. ${ }^{(10)}$ Adolescents girls should be provided with supplements of iron to maintain haemoglobin \& serum ferritin levels above $12 \mathrm{~g} / \mathrm{dl} \&$ maintain $>35 \mathrm{mg} / \mathrm{L}$, respectively for prevention of nutritional anaemia. Unfortunately, millions of adolescents in both high-income countries (HICs) and low and middle-income countries (LMICs) suffer from nutritional disorders. ${ }^{(12)}$

\section{what is anaemia???}

Human blood contains a red pigment called haemoglobin, which is rich in iron. It carries oxygen to different parts of the body. The deficiency of iron in diet leads to decreased amount of haemoglobin, making the blood thin and less red which leads to loss of supply of oxygen to different parts of the body, this state is known as anaemia. ${ }^{(13)}$

\section{Cut off levels of Hemoglobin for diagnosis of Anaemia- ${ }^{(14)}$}

\begin{tabular}{|l|l|}
\hline Age/ Sex & Hb gram/ dl \\
\hline Children 6 to 14 years & 12 \\
\hline Adolescents $15-19$ years & 12 \\
\hline Adult female & 12 \\
\hline Adult female pregnant & 11 \\
\hline
\end{tabular}

If the level falls below those above, then the person is diagnosed as having anaemia.

Classification of anaemia according to WHO

\begin{tabular}{|l|l|}
\hline Mild anaemia & $11.9 \mathrm{gm}$ to $10 \mathrm{gm} \mathrm{Hb} / 100 \mathrm{ml} \mathrm{blood}$ \\
\hline Moderate anaemia & $9.9 \mathrm{gm}$ to $7 \mathrm{gm} \mathrm{Hb} / 100 \mathrm{ml}$ blood \\
\hline Severe anaemia & $<7 \mathrm{gmHb} / 100 \mathrm{ml} \mathrm{blood}$ \\
\hline
\end{tabular}

\section{The concept of nutritional anaemia in Ayurveda -}

The formation and pathogenesis of a disease in Ayurveda is linked with the vitiation of Dosha. Ayurveda described 3 different dosha vata, pitta, kapha which are responsible for a healthy state or causation of disease. Pandu roga is predominantly a result of vitiation of pitta dosha vitiation along with other doshas. Thus, Pandu roga is a tridoshaja (of the three humours) disease. The vitiation of pitta dosha leads to discolouration of the skin \& pallor (Pandu) owing to reduced blood (alpa rakta) or vitiation of blood (vidushya rakta). ${ }^{(15)}$ 


\section{Vedic (Literature review)-}

The word pandu means pallor. In this clinical condition the palpebral conjunctiva, tongue, nail bud turn into pallor, and it has been named Pandu.

Nidana of Pandu roga- (16)

The general aetiology or samanya nidana of Pandu roga is described in charak Samhita which all factors mainly related to Aharaja, viharaja \& nidanarthakara roga.

Pandu Roga is considered as pitta doshapradhana. The provoking factors of pitta can also be taken as a cause of pandu roga.
There are following cause-

- Ritu vaishamya

- Mandhyagni

- Asaatmya aahara

- Vidagadha anna

- Viruddhaa ahara

- Lack of iron supply

- Poor socioeconomic status

- Presence of early age of pregnancy

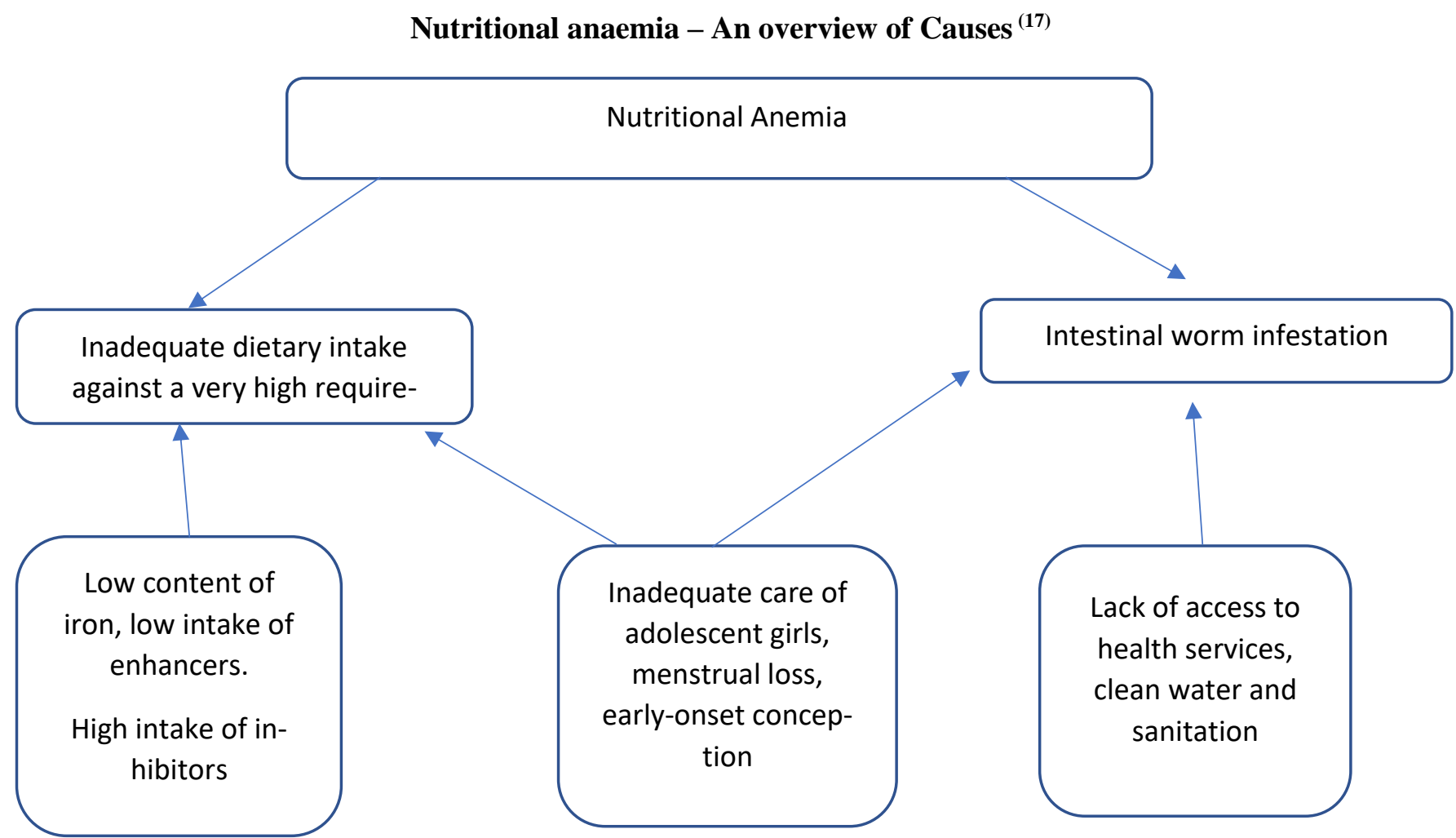

Purvarupa - According to Acharya Charak-

Premonitory signs \& symptoms of Pandu roga are as follows-

- Hridayaspaandana (Palpitation of head)

- Rukshta (roughness)

- Swedabhava (Absence of sweat)

- Twakasphotana (cracking of the skin)

- Gatrasada (General body malaise)

- Mridobhakshana (liking for mud intake)

- Prekshanakutshotha (Swelling over eyelid)
- Vinmutrapita (Yellowish discolouration of faecal matter \& urine)

- Avipaka (Indigestion)

Rupa (Symptoms) ${ }^{(\mathbf{1 8})}$ - durbalata (debility, malaise), Annadwesha (aversion towards foods), annadwesha (aversion towards food), Sharma (exhaustion), Bhrama (giddiness), Hatoprabha (loss of lusture), Irritability, Shishirdweshi (dislike cold things). 


\section{Samprapti ${ }^{(19)}$ -}

Due to Nidana, pitta dosha gets vitiated and expelled by vayu and it reaches the hridaya and from there it spreads through the dasadhamani and mobilizes the entire body and gets localized between tavaka and mamsa. Vitiatedkapha, Vata, Asruk, Tvaka and Mamsa cause tvakavaivarna such as Pandu, Haridra, Harita etc. Along with skin discolouration, there are systemic symptoms like exertion dyspnea, tiredness, breathlessness, leg cramps etc. Such a diseased condition is named Pandu Roga in Ayurveda classics. These all symptoms of Pandu roga in hand with that of Anemia explained modern system of medicine.

\section{Treatment $-{ }^{(20)}$}

- Sodhana- Vamanam and virechanam are done by Snigdha \& tikshna dravyas. Every sodhana karma should be given after snehanam only. Madanphalam is the most suitable drug for Vamana in children. generally, sodhana therapy should be followed with proper care in children.

\section{- Samana chikitsa-}

$\checkmark$ Treatment according to predominant dosha

$\checkmark$ Specific treatment

$\checkmark$ Symptomatic treatment

$\checkmark$ Pathya apathya

\section{Risk factors of Nutritional anaemia-}

- Frequent illness was the most prevalent problem in the daily routine of girls. However, the prevalence of anaemia was more common in girls with the problem of inadequate food. Frequent illness and inadequate food lead to the deficiency of nutrition which is the most common cause of iron deficiency anaemia in India ${ }^{(21)}$

- Heavy menstrual bleeding was found second most common contributing factor for anaemia. Blood loss in adolescent girls leads to anaemia and increased demand for blood, the fact is supported by studies. (22)

- Worm infestation was also a common observation found in anaemic girls.

- Most of the girls were not receiving food from National Program no significant relation was found between anaemia and girls receiving food from the National program other studies report that iron fortification of mid-day meals was effective in significantly reducing the prevalence of anaemia among school children. ${ }^{(23)}$

- Diet- mostly girls were taking vegetarian diet and girls were taking mixed diet. The majority of girls found anaemic were vegetarian. A highly significant association was found between a vegetarian diet and anaemia in girls. This association has been proved in a study that anaemia is more prevalent in vegetarians. ${ }^{(24)}$

Vegetarian's diet tends to be lower than the average requirement for riboflavin \& vitamin B12 deficiencies. ${ }^{(25)}$ The researcher also reports that a vegetarian diet is low in iron \& vitamin B12. ${ }^{(26)}$

- Menarche - anaemia was found more prevalent in girls, who achieved menarche.

- Immunization status- Girls were completely immunized while a maximum number of girls are not immunized. The finding supports ignorance towards health care which may also be the reason for anaemia in these girls.

Formulations of treatment of nutritional anaemiaFour studies were focused on the general population. The Ayurvedic formulations studied in these four studies for their efficacy against IDA among the general population include NavayasaLauha, PunarnavadiMandura, DhatriLauha, PradarantakaLauha, SarvaJvara Hara Lauha, BrihatYakrdariLauha, DadimadiGhrita and TrikatrayadiLauha. There are several explanations regarding the efficacy of Ayurvedic formulations in combating IDA in the general population. It is observed that a substantial portion of these Ayurvedic formulations contain organic matter that includes ascorbic acid, sugars, amino acids, and organic acids, which cause better absorption of non-haem iron. ${ }^{(27)}$ Furthermore, most of the Ayurvedic formulations are administered with some Anupama (vehicle) as in the case of NavayasaLauha and DhatriLauha. These two formulations are administered with honey as Anupana which is a mixture of glucose and fructose, and iron may combine with these sugars for absorption. This is also advocated in Allopathic medicine as iron formulations are combined with sugars such as iron polymaltose complex and ferrous gluconate Punarnavadi 
Mandura and Dhatri Lauha are also administered with buttermilk and the mechanism of action and iron absorption has been explained in this draft. BrihatYakrdariLauha is being administered with a ginger extract which also helps in iron absorption owing to its carbohydrate and protein contents. ${ }^{(28)}$

Rasayana Chikitsa: Ayurveda Rasayana therapy has given a powerful contribution and rejuvenates the body and the mind. Vardhamanpippalirasayana Guduchi Shatavari Laghumalinivasant Dhatriavleha

\section{PATHYA-APATHYA:}

\section{Pathyahara:}

Food - old wheat, rice (shashtika), barley, jowar, green gram and pea.

Vegetables - Dudhi, Patola, Bimbi, Chakvat, Palak, Shepu, Jeevanti, Haridra, Punarnava Non-veg - Shingada fish, goat meat, jangal meat

Fruits - Amla, grapes, anjeer, chikoo, banana, mango, khajur, pomogranate, papaya Roots - Shingada, kamalakunda, lasuna, ginger.

Milk products - Cow milk, ghee, navneetatakra.

Liquids - gomutra, lajamanda, koshnajala, laghu panchamula siddha jala.

Madyavarga - Sauvira and tushodaka.

Ksharavarga - yavakshara Vihara: Light exercise Apathyahara:

Shakavarga - Except for the above-mentioned shakavarga

Shimbivarga - Matara, masha, pinyaka

Dal - Til, sharshapa

Tail varga - Bijowar tail

Drava Varga - Atyambupana, Madyapana

Vihara: Diwaswapna, Atapseva, Ativyayama, Vegavidharana, Chinta, Shoka, Krodha. Agni, Atapa, Pittakaraaharasevana, Maithun, Ayasa, Krodha.

In Ayurveda classic types of mridbhakshanjanyapandu, due to mud intake. have treatment of shodhanchikista i.e. vamanvirechanwhich is prescribed to the girls.

Dosage, duration and Anupana of important Ayurvedic formulations for iron deficiency anemia -

Name of the drug Dosage, Anupana (vehicle), Duration of treatment as per studies -PunarnavadiMandura $250 \mathrm{mg}$ twice daily Buttermilk 30 days the dosage and the duration of treatment reported in various studies were following the need and design of the studies, however the same can be customized according to the need of the patients. In addition, multiple studies have used multiple dosages, however, the convenient dosages have only been mentioned here where the results are statistically significant which helps in avoiding prolonged treatment unnecessarily.

Dosage, duration, and formulations Anupana of important Ayurvedic drugs for iron deficiency anaemia -

Name of the drug Dosage, Anupana (vehicle), Duration of treatment as per studies -DhatriLauha $500 \mathrm{mg}$ thrice daily Buttermilk/honey 30 days

DadimadiGhrita $10 \mathrm{ml}$ twice daily Lukewarm water 84 days

Pandughnivati $500 \mathrm{mg}$ thrice daily Lukewarm water 90 days

TrikatrayadiLauha (suspension form) $0.5 \mathrm{ml} / \mathrm{kg}$ bodyweight Not mentioned 10 weeks TrikatrayadiLauha (tablet) $250 \mathrm{mg} 4$ times daily Not mentioned 60 days NavayasaLauha $250 \mathrm{mg}$ twice daily Honey 30 days. ${ }^{(29)}$

\section{CONCLUSION}

Based on nidana and lakshana pandu can be correlated to iron deficiency anaemia of modern science. From this review, it is evident the most of the ayurvedic formulations were studied for their efficacy against anemia in adolescent girls. Pandu roga showed its direct impact on rasa raktavaha sroto dushti lakshana due to rasa dhatvagni mandyata. Vata pitta prakruti persons and those who follow pittakara nidana persons are more susceptible to pandu. The present lifestyle has disturbed the food habits giving rise to agnimandya, vidhagdhajirna, and finally leads to Pandu roga. Poor Socioeconomic conditions, mental stress and strain play an important role in causing and aggravating the Pandu roga.

\section{REFERENCES}

1. Das JK, Salam RA, Thornburg KL, et al. Nutrition in adolescents: physiology, metabolism \& nutritional needs, Ann N4 science 2017; 1393: 21-23 
2. Dietary reference intakes, The essential guide to nutrient requirements, Washington, DC: The national academic's press: 2006.

3. Pushpamma P, Geervani P, Lakshmi Devi N, food intake, nutrient adequacy and anthropometry of adolescents in Andhra Pradesh, Indian J med Res. 1982, 75:61-67.

4. Sen A, Sengupta S, Malnutrition of rural children $\&$ the sex bias, economic political weekly 1983, 18: 13-14.

5. WHO, nutritional anaemia: Report of a WHO scientific group, technical report series no - 405 geneva, WHO 1968

6. De MAeyer EM, Dallman P, Gurney JM, et al. preventing \& controlling iron deficiency anaemia through primary health care, A guide for health administrations \& programme.

7. Mangers Geneva: WHO 1989 - 9

8. Kushwaha HC, Editor, Charak Samhita of Agnivesha, Part 2, Chikitsasthana Chapter 16, Verse 5, Reprint Edition Varanasi: Chakhamba Orientalia, 2012; 422

9. Care of the newborn - Revised eighth edition - meharban Singh Chapter no. 3 Preventive neonatology, Page no-46

10. Gopalan $\mathrm{C}$ Growth of affluent Indian girls during adolescence, scientific report series no-10 Nutrition foundation of Indian, 1989, Page no. 1-49

11. De MAeyer EM, Dallman P, Gurney JM, et al. preventing \& controlling iron deficiency anaemia through primary health care, A guide for health

12. Das JK, Salam RA, Thornburg KL, et al. Nutrition in adolescents: physiology, metabolism \& nutritional needs, Ann N4 science 2017; 1393: 21-23

13. Bertil Glader. The Anemias. In Nelson Textbook Of Pediatrics. Ed Behman RE et al. 17th edition, Saunders, Philadelphia, 2004: 1604- 1632.

14. Bertil Glader. The Anemias. In Nelson Textbook Of Pediatrics. Ed Behman RE et al. 17th edition, Saunders, Philadelphia, 2004: 1604- 1632.

15. Shastri A, editor, Sushruta Samhita of Sushruta sutra sthana, Version - 12 reprinted Varanasi chaukhamba Sanskrit sansthan 2007 p- 50 chapters 14

16. RK Sharma \& Bhagwan Das editor, Charak Samhita by Agnivesha, Chikistasthana 16 Chaukhamba Sanskrit Series, Varanasi, vol 2, reprint 2005, p.no. 284

17. Bertil Glader. The Anemias. In Nelson Textbook of Pediatrics. Ed Behman RE et al. 17th edition, Saunders, Philadelphia, 2004: 1604- 1632.
18. Charak Samhita of agnivesha, Revised by charak and dridhbala, chaukhambha bharti academy Varanasi, reprint 2012, Chapter 16, page no. 489

19. Charak Samhita of agnivesha, Revised by charak and dridhbala, chaukhambha Bharti academy Varanasi, reprint 2012, Chapter 16, page no. 489

20. Journal of Ayurveda and integrated medical sciences literature review article on anaemia by Dr Chetan A.H.

21. Asokan J.S.et. al.: Prevention of anaemia among adolescent girls, Indian journal paediatrics: 532- 536, 2000.

22. Kapur D. Agrawal: Nutritional anaemia and its control. Indian journal paediatrics 69 (7): 607-16, 2002.

23. Rajini $S$ et al. Prevalence of anaemia and factors among rural adolescent girls. Indian journal of maternal and child health; 2010.

24. Goel S. and B.P. Gupta: Low anaemia prevalence among adolescents. India Journal of community medicine, vol. 32 no. 1: 325-326, 2007.

25. Chaudhary Sanjeev, M.et. al: Anemia among Adolescent Females, Indian Journal of community medicine, vol, 33: 243-245, 2008.

26. Rita Singh, sociodemographic factors causing anaemia in adolescent girls in Meerut. Health and Population Perspectives and issues 2008, 38: 198-203.

27. Perry, C.L., McGuire, M.T., Neumark- Sztainer, D., \& Story, M. adolescent vegetarians. How well do their dietary patterns meet the healthy people 2010 objective? arch.

28. Choudhary SM, Dhage VR, A study of anaemia among adolescent females in the urban area of Nagpur, Indian J Community Med. 2008; 33:243-245

29. International research journal of multidisciplinary studies - anaemia in adolescent girls and Ayurveda by Dr Sonal A. Shah Vol-5

\section{Source of Support: Nil Conflict of Interest: None Declared}

How to cite this URL: Verma Annu et al: Article On Adolescent Nutritional Anemia With Special Reference To Girls. International Ayurvedic Medical Journal \{online\} 2021 \{cited September 2021\} Available from: http://www.iamj.in/posts/images/upload/2099_2104.pdf 